\title{
Potential genesis and implications of calcium nitrate in Antarctic snow
}

\author{
Kanthanathan Mahalinganathan and Meloth Thamban \\ National Centre for Antarctic and Ocean Research, Headland Sada, Vasco-da-Gama, Goa, India \\ Correspondence to: Kanthanathan Mahalinganathan (maha@ncaor.gov.in)
}

Received: 7 September 2015 - Published in The Cryosphere Discuss.: 6 November 2015

Revised: 22 March 2016 - Accepted: 5 April 2016 - Published: 15 April 2016

\begin{abstract}
Among the large variety of particulates in the atmosphere, calcic mineral dust particles have highly reactive surfaces that undergo heterogeneous reactions with atmospheric acids contiguously. The association between $\mathrm{nssCa}^{2+}$, an important proxy indicator of mineral dust, and $\mathrm{NO}_{3}^{-}$, a dominant anion in the Antarctic snowpack, was analysed. A total of 41 snow cores $(\sim 1 \mathrm{~m}$ each) that represent snow deposited during 2008-2009 were studied along coastal-inland transects from two different regions in East Antarctica - the Princess Elizabeth Land (PEL) and central Dronning Maud Land (cDML). Correlation statistics showed a strong association (at $99 \%$ significance level) between $\mathrm{NO}_{3}^{-}$and $\mathrm{nssCa}^{2+}$ at the near-coastal sections of both PEL $(r=0.74)$ and cDML $(r=0.82)$ transects. Similarly, a strong association between these ions was also observed in snow deposits at the inland sections of PEL $(r=0.73)$ and cDML $(r=0.84)$. Such systematic associations between $\mathrm{nssCa}^{2+}$ and $\mathrm{NO}_{3}^{-}$are attributed to the interaction between calcic mineral dust and nitric acid in the atmosphere, leading to the formation of calcium nitrate $\left(\mathrm{Ca}\left(\mathrm{NO}_{3}\right)_{2}\right)$ aerosol. Principal component analysis revealed common transport and depositional processes for $\mathrm{nssCa}^{2+}$ and $\mathrm{NO}_{3}^{-}$both in PEL and cDML. Forward- and back-trajectory analyses using HYSPLIT model v. 4 revealed that southern South America (SSA) was an important dust-emitting source to the study region, aided by the westerlies. Particle size distribution showed that over $90 \%$ of the dust was in the range $<4 \mu \mathrm{m}$, indicating that these dust particles reached the Antarctic region via longrange transport from the SSA region. We propose that the association between $\mathrm{nssCa}^{2+}$ and $\mathrm{NO}_{3}^{-}$occurs during the longrange transport due to the formation of $\mathrm{Ca}\left(\mathrm{NO}_{3}\right)_{2}$ rather than to local neutralisation processes. However, the influence of local dust sources from the nunataks in cDML and the con-
\end{abstract}

tribution of high sea salt in coastal PEL evidently mask such association in the mountainous and coastal regions respectively. Ionic balance calculations showed that $70-75 \%$ of $\mathrm{NO}_{3}^{-}$in the coastal sections was associated with $\mathrm{nssCa}^{2+}$ (to form $\left.\mathrm{Ca}\left(\mathrm{NO}_{3}\right)_{2}\right)$. However, in the inland sections, $50-55 \%$ of $\mathrm{NO}_{3}^{-}$was present as $\mathrm{HNO}_{3}$. The study indicates that the input of dust-bound $\mathrm{NO}_{3}^{-}$contributes a significant fraction of the total $\mathrm{NO}_{3}^{-}$deposited in coastal Antarctic snow.

\section{Introduction}

Fine aerosols from surrounding continents are transported thousands of kilometres and teleconnected with the Antarctic atmosphere. Consequently, the chemistry of the Antarctic atmosphere and its ice sheet is of considerable importance. Apart from sea-salt aerosols, nitrogen oxides (like NO, $\left.\mathrm{NO}_{2}\right)$, nitric acid $\left(\mathrm{HNO}_{3}\right)$, and mineral dust particles make up a significant component in the Antarctic atmosphere (Weller et al., 2002; Albani et al., 2012; Wolff, 2013). Nitrate is ubiquitous in the atmosphere and constitutes a large portion of anions in the Antarctic snow. Several studies have focused on its origin (e.g. Wolff, 1995; Wagenbach et al., 1998; Traversi et al., 2014), seasonal and spatial variations (e.g. Dahe et al., 1992; Lee et al., 2014; Savarino et al., 2007), air-snow interactions (e.g. Antony et al., 2010; Erbland et al., 2013, 2015), and post-depositional processes (e.g. Wagnon et al., 1999; Weller, 2004; Berhanu et al., 2015). However, there are many uncertainties and speculations over the sources of nitrate, its seasonality, and post-depositional losses (e.g. Traversi et al., 2014; Shi et al., 2015).

Natural mineral dust forms an active aerosol component in the atmosphere, and model simulations show that the min- 
eral dust from surrounding continents is directly linked to the Antarctic climate system (e.g. Li et al., 2008; Gassó et al., 2010). These dust particles are evidently an important factor, considering that they alter the chemical and optical properties of the atmosphere (Nousiainen and Kandler, 2015). The mineralogy of dust particles is of critical importance since it plays a major role in deciding the manner in which the dust particles alter the chemistry of the atmosphere (Krueger et al., 2004). Previous field studies and model simulations demonstrate that throughout the world, mineral dust is frequently associated with $\mathrm{NO}_{3}^{-}$(e.g. Jordan et al., 2003; Fairlie et al., 2010). It was reported that almost all of total $\mathrm{NO}_{3}^{-}$in high dust regions and $>40 \%$ of the total $\mathrm{NO}_{3}^{-}$throughout most of the global atmosphere are coupled with mineral dust (Usher et al., 2003). This association, depending on the mineralogical composition of the dust, yields various nitrate-salt products (Gibson et al., 2006). Studies also show that dustassociated $\mathrm{NO}_{3}^{-}$is a large component of total atmospheric $\mathrm{NO}_{3}^{-}$due to the presence of $\mathrm{Ca}^{2+}$ in mineral dust, which has a high buffering capacity to neutralise atmospheric nitric acid $\left(\mathrm{HNO}_{3}\right)$ to yield highly hygroscopic calcium nitrate $\left(\mathrm{Ca}\left(\mathrm{NO}_{3}\right)_{2}\right)$ aerosol (Krueger et al., 2003).

In Antarctica, non-sea-salt $\mathrm{Ca}^{2+}\left(\mathrm{nssCa}^{2+}=\mathrm{Ca}^{2+}-0.038\right.$ $\mathrm{ssNa}^{+}$) has been used as a proxy for mineral dust concentration in ice core records (Ruth et al., 2008; Schüpbach et al., 2013). Röthlisberger et al. (2000) have also documented strong associations between $\mathrm{NO}_{3}^{-}$and $\mathrm{Ca}^{2+}$ throughout the Last Glacial Maximum (LGM), during which dust concentrations in the Antarctic atmosphere were up to 20 times that of the present day. However, such associations between $\mathrm{NO}_{3}^{-}$and $\mathrm{Ca}^{2+}$ have not been widely reported in present-day Antarctic snowpack. In this study, we analyse the spatial variability and association of $\mathrm{NO}_{3}^{-}$and $\mathrm{nssCa}^{2+}$ from two different regions in East Antarctica - Princess Elizabeth Land (PEL) and central Dronning Maud Land (cDML). We also discuss the possible formation processes of $\mathrm{Ca}\left(\mathrm{NO}_{3}\right)_{2}$ during the long-range transport of mineral dust and its significance for Antarctic snow chemistry.

\section{Sampling and methods}

Forty-one snow cores were recovered from the PEL and cDML transects using a KOVACS Mark IV coring system (14 cm diameter) during the summer of 2008-2009 (Fig. 1). Each snow core was about $1 \mathrm{~m}$ deep, enough to cover over 1 year of snow accumulation. Sampling was carried out in such a way that both transects were perpendicular to the coast and overall slope contours of the region. A total of 21 snow cores were retrieved from coast to inland in PEL covering a distance of $180 \mathrm{~km}$ and an elevation of $2100 \mathrm{~m}$ a.s.l. Similarly, in cDML, 20 snow cores were retrieved from the near coast to the inland region, covering a distance of 110-300 km from the coast and an elevation of up to 2800 ma.s.l. Due to the absence of fresh snow over the Nivlisen ice shelf and the

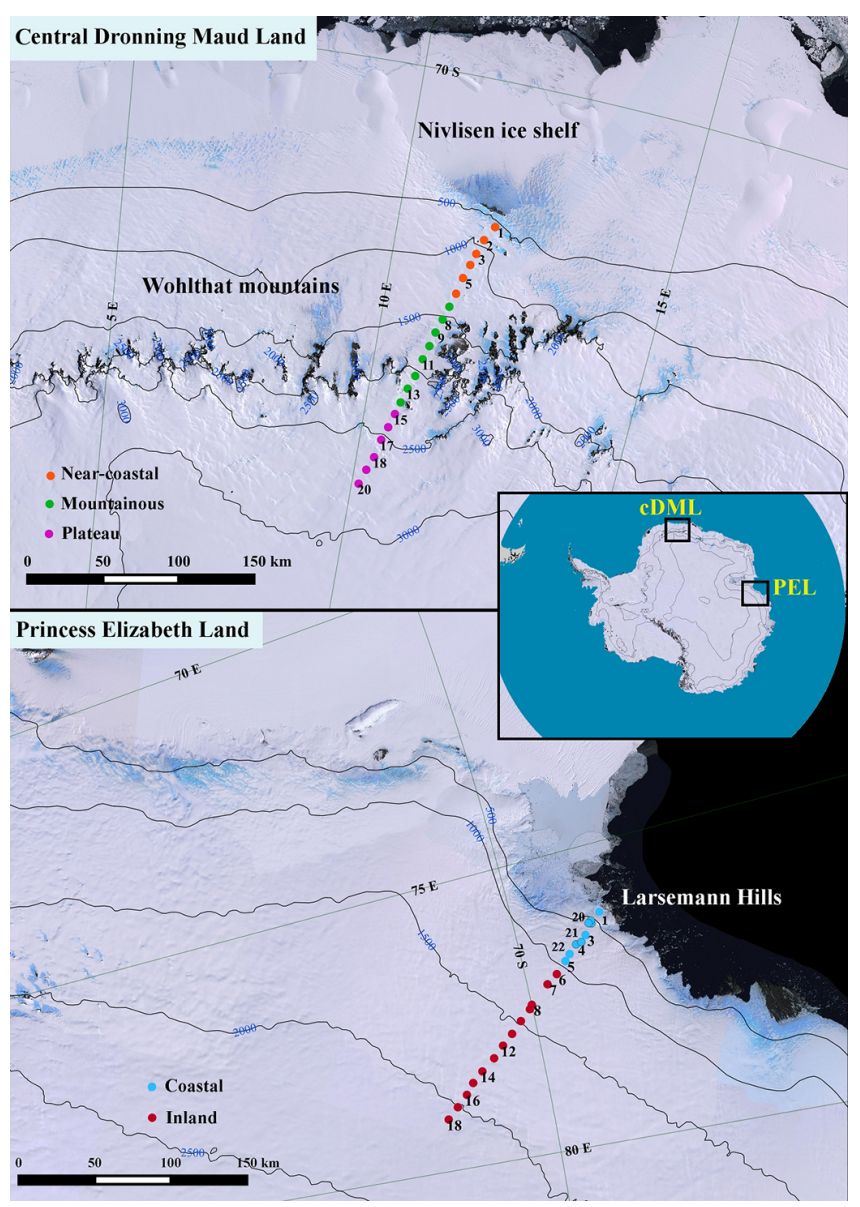

Figure 1. Study region showing sampling locations along transects in central Dronning Maud Land (top panel) and Princess Elizabeth Land (bottom panel), East Antarctica. Colour-coded sampling locations indicate different topographic sections. Inset shows the study area highlighted in Antarctica. Maps were created using LANDSAT Mosaic using QGIS Wien (v.2.8) in conjunction with Quantarctica project.

edge of the ice cap, no cores were collected up to $110 \mathrm{~km}$ from the coast in cDML (Fig. 1). For the sake of clarity, the actual distance from sea $(300 \mathrm{~km})$ is mentioned in cDML throughout this paper. Based on the topography, the cDML transect is spatially divided into near-coastal $(110-160 \mathrm{~km})$, mountainous $(170-240 \mathrm{~km})$, and plateau $(>240 \mathrm{~km})$ sections (Fig. 1).

The snow cores were transferred directly into pre-cleaned high-density polyethylene bags and sealed immediately to avoid any contamination during storage and transport. The sample bags were kept in expanded poly propylene boxes and were stored at $-20^{\circ} \mathrm{C}$ throughout the transit to the ice core laboratory of National Centre for Antarctic and Ocean Research in India. Each core was carefully unpacked and subsampled at $5 \mathrm{~cm}$ resolution under a laminar flow bench housed at $-15^{\circ} \mathrm{C}$ facility. The outer layers of these subsamples were removed manually by ceramic knives and the 
innermost portion of the samples were transferred to precleaned vials. These subsamples were then melted in a class 100 clean room prior to the analyses. Major ion concentrations were analysed using Dionex DX2500 with IonPac CS17 column for cations ( $100 \mu \mathrm{L}$ injection loop) and ICS 2000 with IonPac AS11-HC column for anions $(1000 \mu \mathrm{L}$ injection loop). An excellent low detection limit was achieved for both soluble $\mathrm{Ca}^{2+}\left(0.3 \mu \mathrm{g} \mathrm{L}^{-1}\right)$ and $\mathrm{NO}_{3}^{-}\left(5 \mu \mathrm{g} \mathrm{L}^{-1}\right)$. Reference standards and duplicate samples were analysed in a routine manner to estimate the analytical precision, which was better than $5 \%$ for both the ions. Dust particle concentration and grain size measurements were carried out using a Multisizer 4 Coulter Counter (Beckman), placed in a class 100 clean room. Size calibration was made using polystyrene latex beads of $5 \mu \mathrm{m}$ radius and a precision better than $5 \%$ was obtained.

The seasonality from these snow cores are determined as mentioned in Mahalinganathan et al. (2012). High-resolution $\delta^{18} \mathrm{O}$ records of each core were studied to differentiate the summer and winter snow deposition. Annual layers were identified based on the seasonal differences of $\delta^{18} \mathrm{O}$. A seasonal $\delta^{18} \mathrm{O}$ amplitude of $4 \%$ was considered large enough to represent the temperature difference between summer and winter precipitation (Stenberg et al., 1998). A minimum seasonal amplitude of $6 \%$ in $\delta^{18} \mathrm{O}$ values was observed in all cores (except cores from $110 \mathrm{~km}$ in cDML and from 10, 70, and $100 \mathrm{~km}$ in PEL), which was large enough to differentiate between summer and winter layers.

The concentrations of sea-salt $\mathrm{Na}^{+}$(and, therefore, $\left.\mathrm{nssCa}{ }^{2+}\right)$ were calculated using the equation $\mathrm{ssNa}^{+}=$ $\left(R_{\mathrm{c}} \cdot \mathrm{Na}^{+}-\mathrm{Ca}^{2+}\right) /\left(R_{\mathrm{c}}-R_{\mathrm{m}}\right)$ derived from Röthlisberger et al. (2002b), where $R_{\mathrm{c}}=1.78$ and $R_{\mathrm{m}}=0.038$ are the average ratios of $\mathrm{Ca}^{2+} / \mathrm{Na}^{+}$in crust and marine systems respectively. The $\mathrm{Na}^{+}$and $\mathrm{Ca}^{2+}$ are respective total concentrations in snow.

Ionic balance and residual acidity $\left(\mathrm{H}^{+}\right)$of all snow samples were calculated in terms of $\mu \mathrm{eq} \mathrm{L}^{-1}$ based on the methods specified in Legrand and Mayewski (1997) and Iizuka et al. (2004). In order to identify common sources and/or transport pathways of the species deposited in snow, principal component analysis (PCA) was carried out separately on snow samples from different sections of the transects in both cDML and PEL. A varimax rotation procedure was performed in order to maximise the variances of normalised factor loading across variables for each factor.

\section{Results}

Snow cores from both PEL and cDML clearly showed seasonal variations in $\delta^{18} \mathrm{O}$ and the major ions (Fig. 2). Sea-salt $\left(\mathrm{Na}^{+}\right)$ions peaked mostly during winter and were in sync with the $\delta^{18} \mathrm{O}$ variations. Though $\mathrm{Ca}^{2+}$ and $\mathrm{NO}_{3}^{-}$peaks were not in sync with the $\delta^{18} \mathrm{O}$ or sea-salt signatures, their seasonal variations were well marked in the snow cores (Fig. 2).
The peak values of $\mathrm{NO}_{3}^{-}$and $\mathrm{Ca}^{2+}$ were observed during early spring or summer, in agreement with previous studies (Wagenbach et al., 1998; Weller et al., 2011).

Concentrations of $\mathrm{NO}_{3}^{-}$and nssCa ${ }^{2+}$ ions showed a significant spatial variability along both PEL and cDML transects (Fig. 3). Nitrate concentrations in PEL ranged from 40 to $200 \mu \mathrm{g} \mathrm{L}-1$ with few samples as high as $350 \mu \mathrm{g} \mathrm{L}^{-1}$. Similarly, $\mathrm{NO}_{3}^{-}$in cDML transect ranged from 15 to $350 \mu \mathrm{g} \mathrm{L}^{-1}$ with outliers as high as $450 \mu \mathrm{gL}^{-1}$. Even though $\mathrm{NO}_{3}^{-}$did not follow any systematic trend with changes in distance from the sea, the inland sites were characterised by relatively higher values along both transects.

Non-sea-salt calculations revealed that the majority of $\mathrm{Ca}^{2+}$ was derived from crustal sources in both coastal and inland regions of PEL (81 and $94 \%$ respectively). Similarly, at cDML transect, the majority of $\mathrm{Ca}^{2+}$ in the mountainous $(96 \%)$, near-coast $(92 \%)$, and plateau $(88 \%)$ regions was also from crustal sources. Non-sea-salt $\mathrm{Ca}^{2+}$ concentrations, on the one hand, were significantly lower than that of $\mathrm{NO}_{3}^{-}$and ranged from 10 to $70 \mathrm{\mu g} \mathrm{L}^{-1}$ with few outliers as high as $100 \mu \mathrm{gL}^{-1}$ in PEL (Fig. 3). On the other hand, $\mathrm{nssCa}^{2+}$ concentrations in cDML transect ranged from 5 to $50 \mu \mathrm{g} \mathrm{L}^{-1}$ except along the mountainous region, where it showed a substantial spread with concentrations up to $150 \mu \mathrm{gL}^{-1}$ and outliers as high as $230 \mu \mathrm{g} \mathrm{L}^{-1}$. As a result, the mean $\mathrm{Ca}^{2+}$ concentrations were significantly high along the mountainous section in cDML transect. In the plateau region the $\mathrm{nssCa}^{2+}$ concentrations were very low with a narrow range (4-12 $\left.\mu \mathrm{g} \mathrm{L}^{-1}\right)$ irrespective of seasonal variations.

Ionic balance of the samples from PEL and cDML revealed the dominance of sea salt $\left(\mathrm{Na}^{+}, \mathrm{Mg}^{2+}, \mathrm{K}^{+}\right.$, and $\mathrm{Cl}^{-}$) in the near-coastal cores (PEL 75\%, cDML 50\%) followed by $\mathrm{NO}_{3}^{-}$(PEL $38 \%$, cDML $27 \%$ ), $\mathrm{nssCa}^{2+}$ (PEL $9 \%$, cDML $19 \%$ ), and $\mathrm{nssSO}_{4}^{2-}$ (PEL 9\%, cDML 17\%). The inland samples, however, showed the dominance of $\mathrm{NO}_{3}^{-}$ (PEL $38 \%$, cDML $47 \%$ ) followed by $\mathrm{nssSO}_{4}^{2-}$ (PEL 14\%, cDML $22 \%$ ). Samples from the mountainous section of cDML showed a large fraction of $\mathrm{Ca}^{2+}$ and $\mathrm{SO}_{4}^{2-}$ derived from crustal sources. The $\mathrm{H}^{+}$calculation revealed that samples from all the regions were acidic except PEL coast, which was basic due to its proximity to the open ocean (Fig. 3).

The correlation analysis of $\mathrm{NO}_{3}^{-}$and $\mathrm{nssCa}^{2+}$ with other major ions showed a consistent relationship between $\mathrm{nssCa}^{2+}$ and $\mathrm{NO}_{3}^{-}$from different sections of PEL and cDML transects except in the mountainous section (Table 1). Further, to verify the consistency, samples representing $1 \mathrm{com}-$ plete year (summer-winter pattern) were also evaluated (Fig. 4). Within the near-coastal and the plateau regions of cDML, $\mathrm{NO}_{3}^{-}$showed a significant association with $\mathrm{nssCa}^{2+}$ $(r=0.82$ and 0.85 respectively). Near the coast, a stronger association $(r=0.95)$ was observed in winter snow deposits while the samples from plateau section showed a stronger association throughout the year $(r=0.85)$. Compared to these, snow cores from the mountainous region in cDML did not 


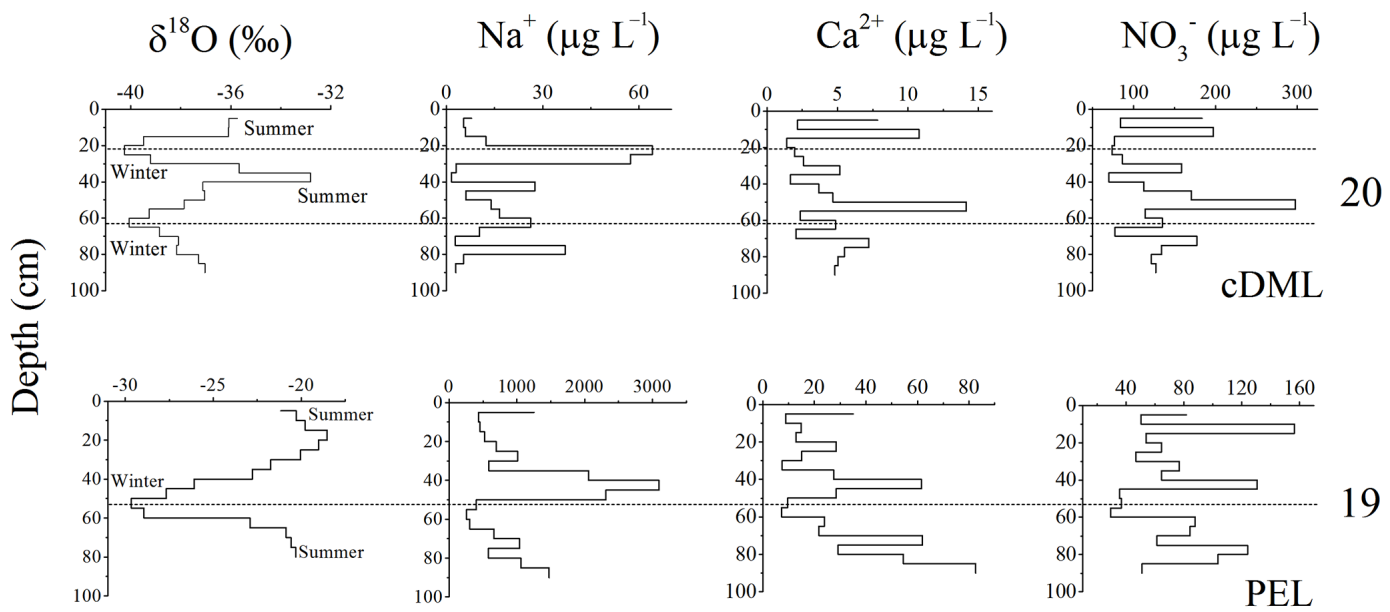

Figure 2. Oxygen isotope ratios and major ions showing seasonality in representative snow cores from inland (cDML, core 20) and coast (PEL, core 19). The dotted lines represent winter maxima in the cores.
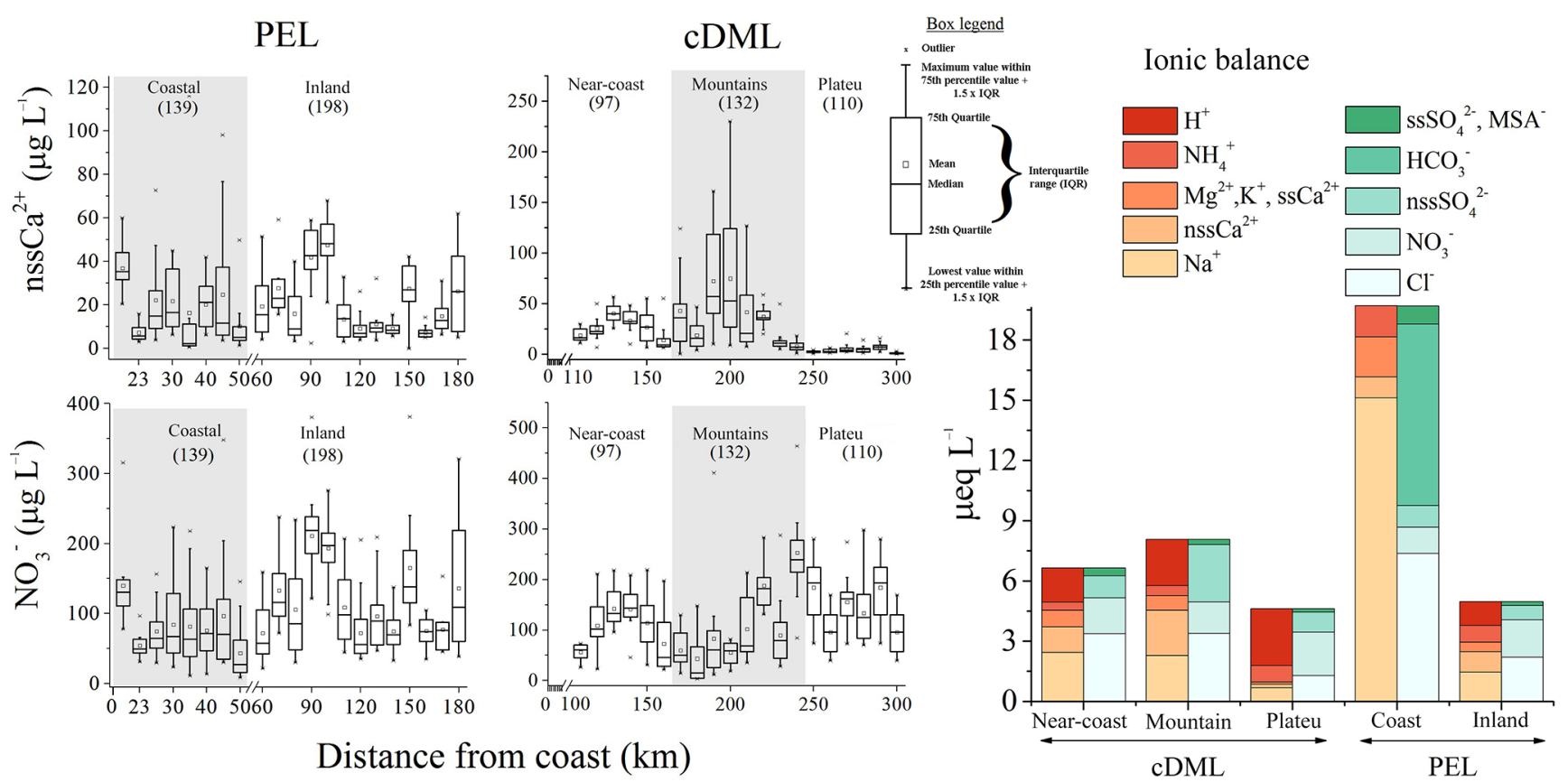

Figure 3. Distribution of $\mathrm{nsCa}^{2+}$ and $\mathrm{NO}_{3}^{-}$concentrations in snow cores along PEL and cDML transects. The numbers inside brackets indicate the total number of samples in respective sections. The balance of ions from all regions are denoted on right panel.

reveal any correlation during winter and showed a comparatively weak correlation only during summer $(r=0.69)$. In PEL transect, $\mathrm{NO}_{3}^{-}$and $\mathrm{nssCa}^{2+}$ showed a more significant relationship in the inland section during winter $(r=0.87)$. The coastal section of PEL showed a consistent relationship throughout the year $(r=0.75)$. All correlations were significant at $99 \%$ confidence level.

The PCA factor loadings are presented in Table 2 where the loadings greater than 0.5 are mentioned in bold. Based on the factor loadings of the marker ions (such as $\mathrm{Na}^{+}, \mathrm{nssCa}^{2+}$, and $\mathrm{MSA}^{-}$), three principal factors (F1, F2, F3) were iden- tified. Those ions primarily derived from sea-spray sources $\left(\mathrm{Na}^{+}, \mathrm{Cl}^{-}, \mathrm{Mg}^{2+}\right.$, and $\left.\mathrm{K}^{+}\right)$and from biogenic sources $\left(\mathrm{MSA}^{-}\right.$and $\left.\mathrm{nsSSO}_{4}^{2-}\right)$ were grouped together. Interestingly, $\mathrm{nssCa}^{2+}$ derived from crustal sources and $\mathrm{NO}_{3}^{-}$derived from upper atmospheric or tropospheric sources were grouped together in all regions, indicating the deposition of these ions in the form of $\mathrm{Ca}\left(\mathrm{NO}_{3}\right)_{2}$ aerosol. However, in the mountainous section of cDML, $\mathrm{nsSCa}^{2+}$ was associated with $\mathrm{nsSO}_{4}^{2-}$, indicating local sources of $\mathrm{nssCa}^{2+}$ from the exposed mountains. 


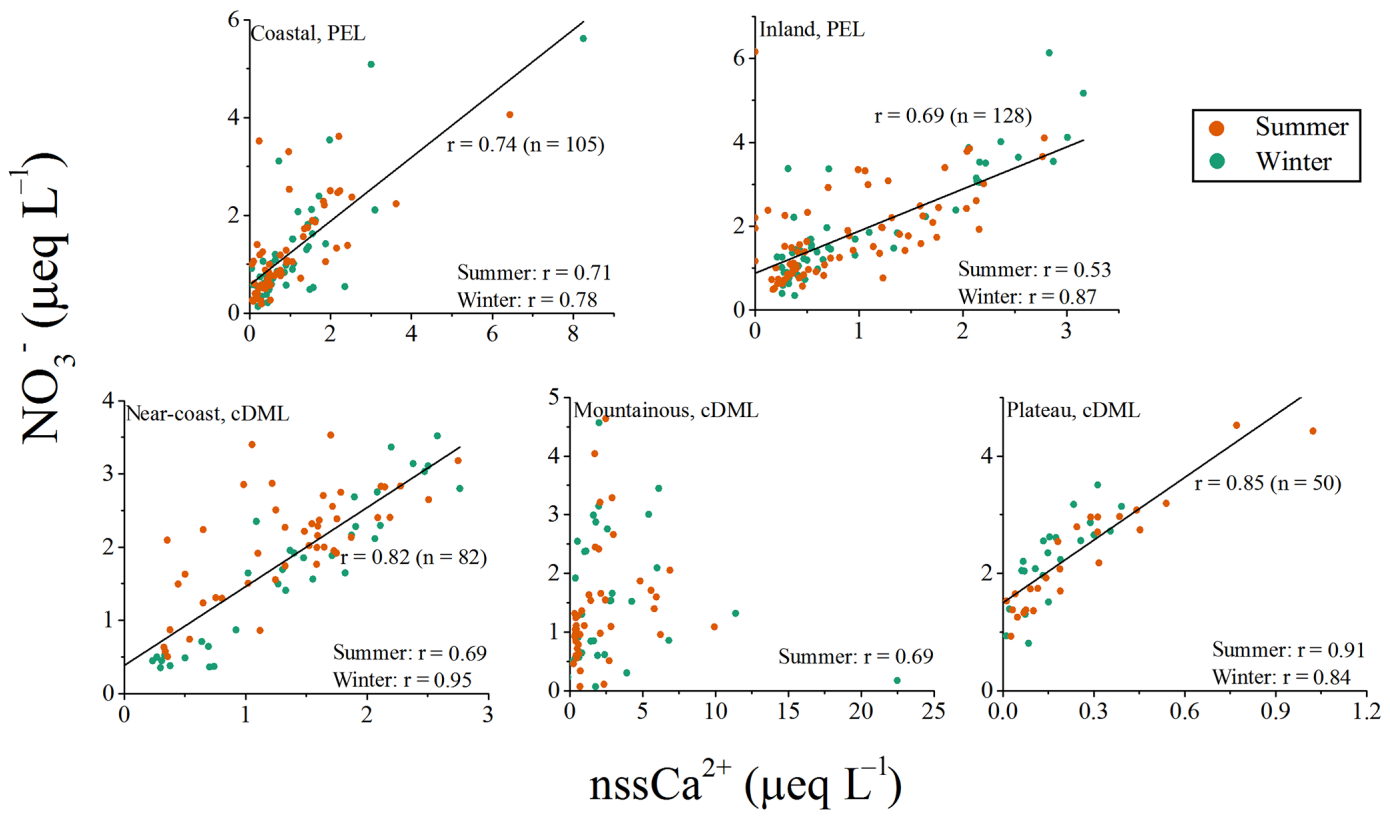

Figure 4. Correlation between $\mathrm{nsSCa}^{2+}$ and $\mathrm{NO}_{3}^{-}$during austral summer (brown) and winter (green) in the study regions in cDML and PEL. Samples representing 1 complete year are plotted here to show the seasonal differences. The samples from coastal and inland sections in both cDML and PEL showed a strong association while the mountainous section in cDML transect showed weak association only during summer.

Table 1. Correlation coefficients of $\mathrm{NO}_{3}^{-}$and $\mathrm{nsSCa}^{2+}$ with other major ions at $99 \%$ significance.

\begin{tabular}{lccccc}
\hline & \multicolumn{3}{c}{ cDML } & \multicolumn{2}{c}{ PEL } \\
& Near-coastal & Mountainous & Plateau & Coastal & Inland \\
\hline & \multicolumn{7}{c}{$\mathrm{NO}_{3}^{-}$} \\
$\mathrm{Na}^{+}$ & - & - & $-0.56^{\mathrm{b}}$ & - & - \\
$\mathrm{K}^{+}$ & - & $0.58^{\mathrm{a}}$ & -0.33 & - & $0.42^{\mathrm{b}}$ \\
$\mathrm{Mg}^{2+}$ & - & $0.41^{\mathrm{a}}$ & - & - & - \\
$\mathrm{nsca}^{2+}$ & 0.82 & $0.69^{\mathrm{a}}$ & 0.85 & 0.74 & 0.69 \\
$\mathrm{NH}_{4}^{+}$ & $0.57^{\mathrm{b}}$ & $0.54^{\mathrm{b}}$ & - & - & - \\
\hline & \multicolumn{7}{c}{$\mathrm{nssCa}^{2+}$} & & \\
$\mathrm{Cl}^{-}$ & - & $0.75^{\mathrm{b}}$ & - & - & - \\
$\mathrm{nssSO}_{4}^{2-}$ & - & 0.92 & - & 0.49 & - \\
\hline
\end{tabular}

Correlations only during ${ }^{\mathrm{a}}$ summer and ${ }^{\mathrm{b}}$ winter.

\section{Discussion}

\subsection{Association between $\mathrm{nssCa}^{2+}$ and $\mathrm{NO}_{3}^{-}$in snowpack from distinct transects}

Nitrate is one of the major anions with multiple sources in the Antarctic environment. It is predominantly a secondary product produced via oxidation of $\mathrm{NO}_{x}$ and photo-dissociation of $\mathrm{N}_{2}$ in the upper atmosphere (Brasseur and Solomon, 1986) and also via sedimentation from polar stratospheric clouds (Legrand and Delmas, 1986; Legrand and Mayewski, 1997). Both stratospheric and tropospheric transport of $\mathrm{HNO}_{3}$ is thought to contribute to $\mathrm{NO}_{3}^{-}$deposited in the Antarctic snow (Legrand and Delmas, 1986; Michalski et al., 2005). Furthermore, it is known that post-depositional processes and photochemical mechanisms also lead to $\mathrm{NO}_{3}^{-}$loss in low-accumulation sites (Röthlisberger et al., 2002a; Erbland et al., 2013), resulting in a complex distribution of $\mathrm{NO}_{3}^{-}$in the Antarctic snowpack. Due to the variety of its sources, $\mathrm{NO}_{3}^{-}$distribution in modern-day snowpack is found to be independent of oceanic or topographic influences and is generally expected to have poor relationships with other major ions. A study of surface snow chemistry across the Antarctic ice sheet by Bertler et al. (2005) also indicated that $\mathrm{NO}_{3}^{-}$ has no clear associations either with parameters like distance from coast and elevation or with other major ions. However, more recent studies (e.g. Erbland et al., 2013, 2015) have shown that $\mathrm{NO}_{3}^{-}$indeed shows spatial variation at least on the surface snow with high concentrations in the interior of the continent. Even though $\mathrm{NO}_{3}^{-}$concentrations in both PEL and cDML did not show clear variation with distance from sea (Fig. 3), ionic balance clearly revealed an overall increase in $\mathrm{NO}_{3}^{-}$concentration towards inland, indicating a rather mixed input of $\mathrm{NO}_{3}^{-}$in the study region.

Compared to $\mathrm{NO}_{3}^{-}$, sources of $\mathrm{Ca}^{2+}$ in the Antarctic environment are relatively well known. A small but significant amount of $\mathrm{Ca}^{2+}$ derived from sea spray and sea ice surface $\left(\mathrm{ssCa}^{2+}\right)$ is present in the coastal section of Antarctic snow (Sommer et al., 2000). Sea-salt $\mathrm{Ca}^{2+}$ may also originate from ikaite crystals $\left(\mathrm{CaCO}_{3} \cdot 6 \mathrm{H}_{2} \mathrm{O}\right)$ in the Antarctic sea ice during onset of winter (Dieckmann et al., 2008). Calculations from 
Table 2. PCA results for samples from all sampling regions. Factor loadings above 0.5 are highlighted.

\begin{tabular}{|c|c|c|c|c|c|c|c|c|c|c|c|c|c|c|c|}
\hline \multirow[b]{2}{*}{ Factors } & \multicolumn{6}{|c|}{$\begin{array}{c}\text { cDML } \\
\text { Mountainous }\end{array}$} & \multicolumn{3}{|c|}{ Plateau } & \multicolumn{6}{|c|}{ PEL } \\
\hline & $\mathrm{F} 1$ & $\mathrm{~F} 2$ & F3 & $\mathrm{F} 1$ & $\mathrm{~F} 2$ & F3 & $\mathrm{F} 1$ & F2 & F3 & $\mathrm{F} 1$ & F2 & F3 & $\mathrm{F} 1$ & $\mathrm{~F} 2$ & $\mathrm{~F} 3$ \\
\hline $\mathrm{Na}^{+}$ & 0.98 & 0.05 & 0.15 & 0.96 & 0.07 & 0.11 & 0.31 & -0.20 & 0.87 & 0.91 & 0.17 & 0.08 & 0.96 & 0.04 & 0.03 \\
\hline $\mathrm{Cl}^{-}$ & 0.95 & -0.05 & 0.14 & 0.94 & 0.07 & 0.16 & 0.67 & -0.25 & 0.51 & 0.70 & 0.30 & 0.21 & 0.93 & -0.01 & 0.17 \\
\hline $\mathrm{Mg}^{2+}$ & 0.97 & 0.01 & 0.14 & 0.82 & -0.09 & 0.4 & 0.37 & 0.09 & 0.81 & 0.81 & 0.4 & 0.09 & 0.88 & -0.04 & 0.14 \\
\hline $\mathrm{K}^{+}$ & 0.63 & 0.44 & 0.23 & 0.76 & 0.26 & 0.43 & 0.19 & 0.1 & 0.86 & 0.83 & 0.39 & 0.09 & 0.73 & 0.23 & -0.04 \\
\hline $\mathrm{Ca}^{2+}$ & 0.11 & 0.96 & 0.05 & 0.26 & -0.01 & 0.91 & 0.09 & 0.91 & 0.16 & 0.38 & 0.87 & -0.02 & 0.09 & 0.96 & -0.02 \\
\hline $\mathrm{nssCa}^{2+}$ & 0.01 & 0.97 & 0.11 & 0.28 & -0.09 & 0.91 & 0.03 & 0.94 & 0.01 & 0.19 & 0.90 & -0.03 & 0.02 & 0.97 & -0.02 \\
\hline $\mathrm{NO}_{3}^{-}$ & -0.2 & 0.83 & 0.19 & -0.09 & 0.77 & 0.01 & 0.01 & 0.95 & -0.05 & -0.07 & 0.80 & 0.27 & -0.05 & 0.90 & 0.23 \\
\hline $\mathrm{NH}_{4}^{+}$ & 0.17 & 0.75 & 0.29 & 0.21 & 0.70 & -0.03 & -0.1 & 0.44 & 0.77 & 0.67 & -0.22 & 0.21 & 0.21 & 0.18 & -0.03 \\
\hline $\mathrm{SO}_{4}^{2-}$ & 0.41 & 0.1 & 0.88 & 0.38 & 0.64 & 0.54 & 0.94 & 0.07 & 0.24 & 0.56 & 0.27 & 0.67 & 0.28 & -0.05 & 0.90 \\
\hline $\mathrm{nssSO}_{4}^{2-}$ & 0.2 & 0.23 & 0.93 & 0.26 & 0.64 & 0.58 & 0.95 & 0.16 & 0.11 & -0.18 & 0.05 & 0.75 & -0.08 & 0.05 & 0.93 \\
\hline $\mathrm{MSA}^{-}$ & -0.11 & 0.12 & 0.89 & 0.11 & 0.21 & 0.55 & 0.76 & -0.08 & 0.22 & 0.34 & -0.08 & 0.73 & 0.38 & 0.01 & -0.13 \\
\hline $\mathrm{H}^{+}$ & 0.29 & 0.08 & 0.71 & -0.05 & 0.76 & -0.3 & 0.63 & 0.62 & 0.03 & -0.36 & 0.17 & 0.44 & 0.14 & 0.24 & 0.79 \\
\hline $\mathrm{HCO}_{3}^{-}$ & n.a. & n.a. & n.a. & n.a. & n.a. & n.a. & n.a. & n.a. & n.a. & 0.77 & -0.10 & -0.20 & n.a. & n.a. & n.a. \\
\hline
\end{tabular}

the coastal section of PEL showed an input of $33 \% \mathrm{ssCa}^{2+}$ (of total $\mathrm{Ca}^{2+}$ ) due to its proximity to the open ocean. Crustal dust from local sources and remote continents are the major sources of $\mathrm{Ca}^{2+}$ (in the form of $\mathrm{nssCa}^{2+}$ ) in the Antarctic atmosphere and ice sheet (Boutron and Martin, 1980). The percentage of estimated $\mathrm{nsSCa}^{2+}$ component in the total $\mathrm{Ca}^{2+}$ in both PEL $(>87 \%)$ and cDML $(>90 \%)$ transects (Fig. 3) supports a predominantly crustal origin of $\mathrm{Ca}^{2+}$ in the study regions. Many ice core studies have demonstrated that dust flux archived in the Antarctic ice sheet was predominantly transported from southern South America (SSA) and/or Australia (e.g. Basile-Doelsch et al., 1997; Delmonte et al., 2004; Revel-Rolland et al., 2006). Furthermore, particle size analyses of dust from snow cores in coastal, mountainous, and inland sections of both cDML and PEL transects showed that $>90 \%$ of particles were $<4 \mu \mathrm{m}$ and the majority of them in the $\sim 1 \mu \mathrm{m}$ size range, indicating a distant dust source as demonstrated by model studies (e.g. Li et al., 2008, 2010).

Local sources of dust in Antarctica are usually limited to ice-free coastal areas, nunataks, and exposed mountainous regions (Tegen and Lacis, 1996; Mahowald et al., 2013). Snow cores from the mountainous section of the cDML transect revealed a significant number of coarser particles $(>10 \mu \mathrm{m})$ as well as visibly insoluble particles along with a large amount of fine particles. Such coarser particles invariably indicate the influence of locally derived dust, especially from the Wohlthat mountains, in the prevailing wind direction (Fig. 1).

This study revealed a striking relationship between $\mathrm{NO}_{3}^{-}$ and $\mathrm{nssCa}^{2+}$ in snow cores from both PEL and cDML transects in East Antarctica that are $>2000 \mathrm{~km}$ apart (Fig. 4). The $\mathrm{Ca}^{2+}$ flux calculations $\left(F_{\mathrm{Ca}^{2+}}=C_{\mathrm{Ca}^{2+}} \times A\right.$, where $C_{\mathrm{Ca}^{2+}}=$ annual mean concentration of $\mathrm{Ca}^{2+}$ and $A=$ annual accumulation) (Burkhart et al., 2004) showed an average of
6.1 and $9.1 \mathrm{~kg} \mathrm{~km}^{-2} \mathrm{yr}^{-1}$ of $\mathrm{Ca}^{2+}$ at PEL and cDML transects respectively, indicating a substantial amount of $\mathrm{Ca}^{2+}$ reaching the Antarctic environment throughout the year. Calcium concentrations in the mountainous section were nearly 3 times higher than the rest of the cDML transect, with concentrations of up to 150 to $230 \mu \mathrm{gL}^{-1}$, strongly implying additional dust input from the Wohlthat mountains in this sector. Also, results from particle size analyses revealed that along with particles under $1 \mu \mathrm{m}$ range, about $22 \%$ of particles present were $>6 \mu \mathrm{m}$, implying dust locally derived from the Wohlthat mountains in the vicinity. Such additional input of nssCa ${ }^{2+}$ from local dust sources possibly obscures the $\mathrm{nssCa}^{2+} / \mathrm{NO}_{3}^{-}$association formed during long-range transport, resulting in poor correlation of $\mathrm{NO}_{3}^{-}$and $\mathrm{nssCa}^{2+}$ as observed in the mountainous section of the cDML transect. Moreover, the association between $\mathrm{NO}_{3}^{-}$and $\mathrm{nssCa}^{2+}$ was consistent in snow deposited during both summer and winter throughout the coastal and inland regions of both the PEL and cDML transects (Fig. 4). The excellent correlation between $\mathrm{NO}_{3}^{-}$and $\mathrm{nssCa}^{2+}$ concentrations at all sites (except the mountainous section) strongly suggest that aerosol interactive processes during long-range transport are responsible for influencing their relationship.

\subsection{Mineral dust reactivity and possible remote sources}

While mineral dust aerosol is often discussed as a single entity aerosol, its chemical characteristics depends on the mineralogy of specific source regions. It is a complex mixture with major minerals like quartz, feldspar, hydrous aluminium silicates, and carbonates (Pye, 1987). Mineral dust reactivity with trace gases in the atmosphere depends on the composition of the dust itself (Laskin et al., 2005). Carbonates such as calcite $\left(\mathrm{CaCO}_{3}\right)$ and dolomite $\left(\mathrm{CaMg}\left(\mathrm{CO}_{3}\right)_{2}\right)$ are found to be the most reactive constituents of mineral dust in the atmosphere in the presence of $\mathrm{HNO}_{3}$ (Usher et al., 2003; 
Krueger et al., 2004). Nitrate salts such as $\mathrm{Ca}\left(\mathrm{NO}_{3}\right)_{2}$ and $\mathrm{Mg}\left(\mathrm{NO}_{3}\right)_{2}$ are formed when calcic mineral dust undergoes heterogeneous reactions with atmospheric $\mathrm{HNO}_{3}$ according to the following reactions (Gibson et al., 2006):

$$
\begin{aligned}
& \mathrm{CaCO}_{3}+2 \mathrm{HNO}_{3} \stackrel{\% \mathrm{RH}}{\longrightarrow} \mathrm{Ca}\left(\mathrm{NO}_{3}\right)_{2}+\mathrm{CO}_{2}+\mathrm{H}_{2} \mathrm{O} \\
& \mathrm{CaMg}\left(\mathrm{CO}_{3}\right)_{2}+4 \mathrm{HNO}_{3} \stackrel{\% \mathrm{RH}}{\longrightarrow} \mathrm{Ca}\left(\mathrm{NO}_{3}\right)_{2} \\
& \quad+\mathrm{Mg}\left(\mathrm{NO}_{3}\right)_{2}+2 \mathrm{CO}_{2}+2 \mathrm{H}_{2} \mathrm{O} .
\end{aligned}
$$

Similarly, there exists a possibility that $\mathrm{N}_{2} \mathrm{O}_{5}$ present in atmosphere can also react with the calcic mineral dust according to the following reactions:

$$
\begin{aligned}
& \mathrm{CaCO}_{3}+\mathrm{N}_{2} \mathrm{O}_{5} \stackrel{\% \mathrm{RH}}{\longrightarrow} \mathrm{Ca}\left(\mathrm{NO}_{3}\right)_{2}+\mathrm{CO}_{2} \\
& \mathrm{CaMg}\left(\mathrm{CO}_{3}\right)_{2}+2 \mathrm{~N}_{2} \mathrm{O}_{5} \stackrel{\% \mathrm{RH}}{\longrightarrow} \mathrm{Ca}\left(\mathrm{NO}_{3}\right)_{2}+\mathrm{Mg}\left(\mathrm{NO}_{3}\right)_{2} \\
& \quad+2 \mathrm{CO}_{2} .
\end{aligned}
$$

The reaction between mineral dust and atmospheric $\mathrm{HNO}_{3}$ or $\mathrm{N}_{2} \mathrm{O}_{5}$ is enhanced in the presence of $\mathrm{H}_{2} \mathrm{O}$ (Goodman et al., 2000). First, $\mathrm{HNO}_{3}$ is adsorbed on the dust surface to form thin layers of $\mathrm{Ca}\left(\mathrm{NO}_{3}\right)_{2}$, even at very low relative humidity $(\mathrm{RH})$ conditions $(\sim 12 \% \mathrm{RH})$ (Al-Abadleh et al., 2003). Then, with increasing $\mathrm{RH}$, the adsorbed $\mathrm{HNO}_{3}$ reacts with bulk $\mathrm{CaCO}_{3}$ or $\mathrm{CaMg}\left(\mathrm{CO}_{3}\right)_{2}$ to form $\mathrm{Ca}\left(\mathrm{NO}_{3}\right)_{2}$. However, this reaction in the atmosphere is limited by the availability of $\mathrm{HNO}_{3}$ (Laskin et al., 2005). Similarly, laboratory studies have shown that $\mathrm{N}_{2} \mathrm{O}_{5}$ hydrolysis on mineral dust particles is enhanced in the presence of higher relative humidity (Mogili et al., 2006).

Several ice core and model studies have demonstrated that certain regions in SSA like northern Patagonia, Puna Altiplano, and San Julian's Great Depression (GD) are the main dust-emitting sources to East Antarctica (Gaiero, 2007; Lambert et al., 2008; Li et al., 2008, 2010). Studies based on large volumes of surface snow samples at Berkner Island by Bory et al. (2010) also showed that the SSA is the dominant dust source in the Atlantic sector of Antarctica. The mineralogical composition of loess and loessoid sediments in SSA reveals the presence of calcic-rich plagioclase and calcite minerals in the dust (Zárate, 2003) that react with $\mathrm{HNO}_{3}$.

The SSA region is a land mass extending from 40 to $56^{\circ} \mathrm{S}$ and the climate here is controlled mainly by the westerlies from the Pacific Ocean (Iriondo, 2000). The atmospheric circulation in Patagonia is dominated by strong meridional pressure gradients that promote strong westerlies and high wind speeds throughout the year (Coronato, 1993). Owing to extreme dryness of the air (with relative humidity as low as $5 \%$ ) in the Patagonian region, the westerlies pick up large volumes of dust, which rise up into the atmosphere (Iriondo, 1989). Furthermore, meridional surface winds and subtropical jet stream intensify, resulting in very strong winds that lead to sizeable dust storms (Gaiero et al., 2013) moving towards the south and east. The Reactions (R1)-(R4) show that under humid conditions, $\mathrm{HNO}_{3}$ strongly promotes the hydrolysis process. Though the extremely low RH conditions in the Patagonian region might not be adequate for hydrolysis, partial solvation could initially provide a reactive site to $\mathrm{HNO}_{3}$ (Usher et al., 2003), followed by further reaction enhanced by the increasing RH over the Southern Ocean.

Results from the ionic balance calculations provided more insight into the associations between $\mathrm{nssCa}^{2+}$ and $\mathrm{NO}_{3}^{-}$in snow (Fig. 3). The ratio of $\mathrm{Cl}^{-} / \mathrm{Na}^{+}$and the correlation coefficients (Table 1) indicated that the sea-salt ions were well preserved throughout PEL and cDML transects. An estimated $70 \%$ of $\mathrm{NO}_{3}^{-}$was associated with the $\mathrm{nssCa}^{2+}$ (in the form of $\left.\mathrm{Ca}\left(\mathrm{NO}_{3}\right)_{2}\right)$ as calculated from the ratio of $\mathrm{nssCa}^{2+}$ and $\mathrm{NO}_{3}^{-}$. However, in the inland region, only an estimated $10 \%$ of $\mathrm{NO}_{3}^{-}$was present as $\mathrm{Ca}\left(\mathrm{NO}_{3}\right)_{2}$ whereas about $53 \%$ of $\mathrm{NO}_{3}^{-}$was present as $\mathrm{HNO}_{3}$ and the rest as $\mathrm{NH}_{4}^{+}$. The nssCa ${ }^{2+}$ associated $\mathrm{NO}_{3}^{-}$was $\sim 75$ and $55 \%$ in the coastal and inland regions of PEL transect respectively. An estimated $25 \%$ of $\mathrm{NO}_{3}^{-}$was present as $\mathrm{HNO}_{3}$ in both the coastal and inland sections of PEL. The estimated values of $\mathrm{NO}_{3}^{-}$present as $\mathrm{Ca}\left(\mathrm{NO}_{3}\right)_{2}$ in PEL transect were relatively higher when compared to the cDML transect. This variation is more likely due to the fact that the PEL transect covers $180 \mathrm{~km}$ from the open ocean whereas the cDML covers a more interior region $(300 \mathrm{~km})$.

The results from PCA analysis displayed $\mathrm{nssCa}^{2+}$ and $\mathrm{NO}_{3}^{-}$strongly grouped within the same factor, indicating that the $\mathrm{nssCa}^{2+}-\mathrm{NO}_{3}^{-}$association occurred due either to the reaction during long-range transport or to a similar reaction in the Antarctic boundary layer. Also, the atmospheric moisture content plays an important role in enhancing the reaction between these two components as shown in the Reactions (R1)(R2) above. It is well known that the moisture content in the Antarctic atmosphere is very low and varies significantly in coastal and inland regions. Besides, the atmospheric boundary layer above the Antarctic ice sheet is only a few tens of metres above the ground level, thereby limiting the reaction times before deposition. Such conditions suggest that predominantly the neutralisation of calcium-dust by $\mathrm{HNO}_{3}$ occurs during long-range transport rather than locally in the boundary layer. Such correlations have also been reported in aerosol studies from the interior Dome $\mathrm{C}$ region (Udisti et al., 2004), where $\mathrm{nssCa}^{2+}$ and $\mathrm{NO}_{3}^{-}$association in aerosol was attributed to the processes during long-range transport of air masses rather than to local neutralisation processes. The mountainous region of cDML showed a completely different association of $\mathrm{nssCa}^{2+}$ and $\mathrm{NO}_{3}^{-}$with the factors. The association of $\mathrm{nsSCa}^{2+}$ with $\mathrm{nsSSO}_{4}^{2-}$ clearly indicates the influence from the exposed mountains in the vicinity. The coastal section of PEL also showed a weak loading of $\mathrm{nssSO}_{4}^{2-}$ along with a strong loading of $\mathrm{nssCa}^{2+}$ and $\mathrm{NO}_{3}^{-}$in the same factor.

To further verify the possible dust sources, 9-day forward and back trajectories for every day at 6-hourly interval for 
austral winter (JJA) and summer (DJF) during 2008-2009 were reconstructed using the NOAA HYSPLIT model v.4 (Draxler and Rolph, 2014) in conjunction with the Global Data Assimilation System data sets (Fig. 5). The forward trajectories were calculated from two prominent dust-emitting hotspots in the SSA region (Li et al., 2010), the North Patagonia $\left(44^{\circ} \mathrm{S}, 67^{\circ} \mathrm{W}\right.$; NP in Fig. 5), and San Julian's GD ( $49^{\circ} \mathrm{S}$, $69^{\circ} \mathrm{W}$; GD in Fig. 5). The back trajectories were calculated from sampling sites representing coastal, mountainous, and inland sections of cDML and PEL. A total of 368 trajectories during winter and 360 trajectories during summer at each location were subjected to a statistical treatment, wherein all trajectories were clustered with lower spatial variance. The forward-trajectory clusters revealed that both during summer (NP: 66\%; GD: $80 \%$ ) and winter (NP: $48 \%$; GD: $42 \%$ ), dust-laden air parcels generally circulate towards south and east from dust sources. The back-trajectory clusters revealed, in line with previous studies (Li et al., 2008, 2010), that the majority of air parcels at $1500 \mathrm{~m}$ level invariably arrived from regions that are influenced by the air parcels from SSA region. These air parcels ultimately get incorporated into the Antarctic circumpolar vortex (ACV) before mass compensation by anticyclonic polar easterlies in the East Antarctic region (Dixon et al., 2012). Both forward- and back-trajectory clusters show that dust reaching the East Antarctic region is a blend of SSA dust sources that feed into the ACV.

\subsection{Formation of calcium nitrate and its significance for the Antarctic snow chemistry}

During their transport from SSA over the Southern Ocean, calcic mineral dust particles readily undergo hydrolysis with atmospheric $\mathrm{HNO}_{3}$ or $\mathrm{N}_{2} \mathrm{O}_{5}$ as described in Reactions (R1)(R4) above. Higher RH levels over the Southern Ocean more likely aid the effortless conversion of $\mathrm{CaCO}_{3}$ to $\mathrm{Ca}\left(\mathrm{NO}_{3}\right)_{2}$. Such progressive reactivity of $\mathrm{CaCO}_{3}$ has been observed in laboratory studies (Krueger et al., 2003; Mogili et al., 2006). A simplified schematic diagram depicting the possible mechanism and processes involved in the formation and deposition of $\mathrm{Ca}\left(\mathrm{NO}_{3}\right)_{2}$ aerosol is shown in Fig. 6. The initial process involves hydrolysis of $\mathrm{HNO}_{3}$ on calcium-rich dust particles from SSA enhanced by relatively higher RH over the Southern Ocean. The anticyclonic polar easterlies sink the air masses reaching the Antarctic atmosphere from the westerly wind belt (Dixon et al., 2012). The air mass containing dust particles upon reaching the Antarctic region undergoes mass compensation within the easterlies, leading to the deposition of aerosols and dust particles to the Antarctic surface (Iriondo, 2000). It is therefore proposed that the availability of calcic mineral dust from SSA under the influence of westerlies and its reaction with atmospheric $\mathrm{HNO}_{3}$ over the Southern Ocean has facilitated the formation of $\mathrm{Ca}\left(\mathrm{NO}_{3}\right)_{2}$ aerosol and this would explain the strong association between $\mathrm{nssCa}^{2+}$ and $\mathrm{NO}_{3}^{-}$in Antarctic snow. Such a reasoning is also consistent with the poor relationship between $\mathrm{nsSCa}^{2+}$

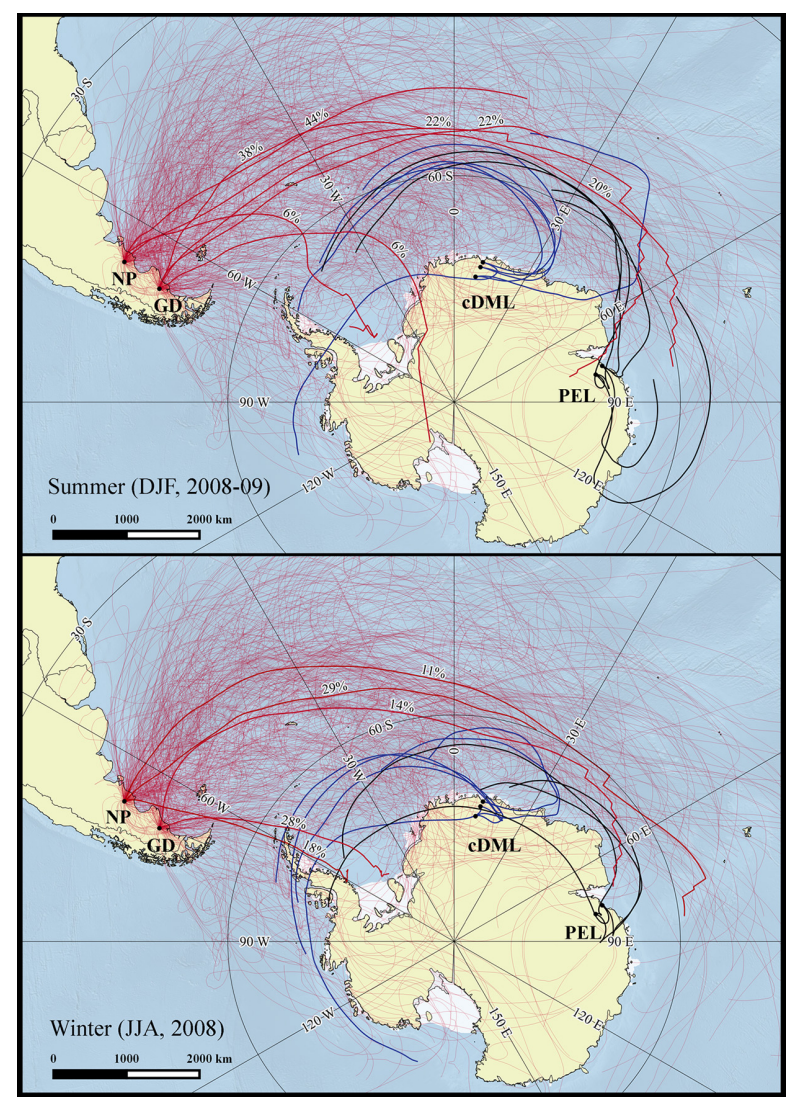

Figure 5. Forward- and back-trajectory analyses for 9 days using HYSPLIT model v.4 in conjunction with Global Data Assimilation System data set. The forward trajectories (red) were calculated from North Patagonia (NP) and San Julian's Great Depression (GD), and the back trajectories (blue, black) were reconstructed from cDML and PEL. The cloud of thin red lines indicate clusters of 6-hourly forward trajectories while the thick red lines show the cluster average. The thick blue and black lines from cDML and PEL region respectively indicate the cluster average of back trajectories calculated during the same time period.

and $\mathrm{NO}_{3}^{-}$reported from sites in proximity to mountainous regions, which provide additional local dust that has not undergone any atmospheric chemical processes.

Interestingly, the present findings have important implications for Antarctic snow chemistry. It is considered that $\mathrm{NO}_{3}^{-}$ in Antarctica is usually deposited in the form of gaseous $\mathrm{HNO}_{3}$, scavenged by or temporarily adsorbed on snow crystals (Wagnon et al., 1999) with significant dry deposition (Davis et al., 2008). Our study implies that apart from gaseous $\mathrm{HNO}_{3}$ and $\mathrm{NO}_{3}^{-}$from polar stratospheric clouds, dust-bound $\mathrm{NO}_{3}^{-}$could also constitute a significant amount of $\mathrm{NO}_{3}^{-}$deposited in Antarctic snow. Similar $\mathrm{Ca}^{2+} / \mathrm{NO}_{3}^{-}$ association has been observed in deep ice cores from Vostok (Legrand et al., 1999) and Dome C (Röthlisberger et al., 2002a), which was attributed to the high amount of dust in the atmosphere during LGM. Studies by Lunt and Valdes 


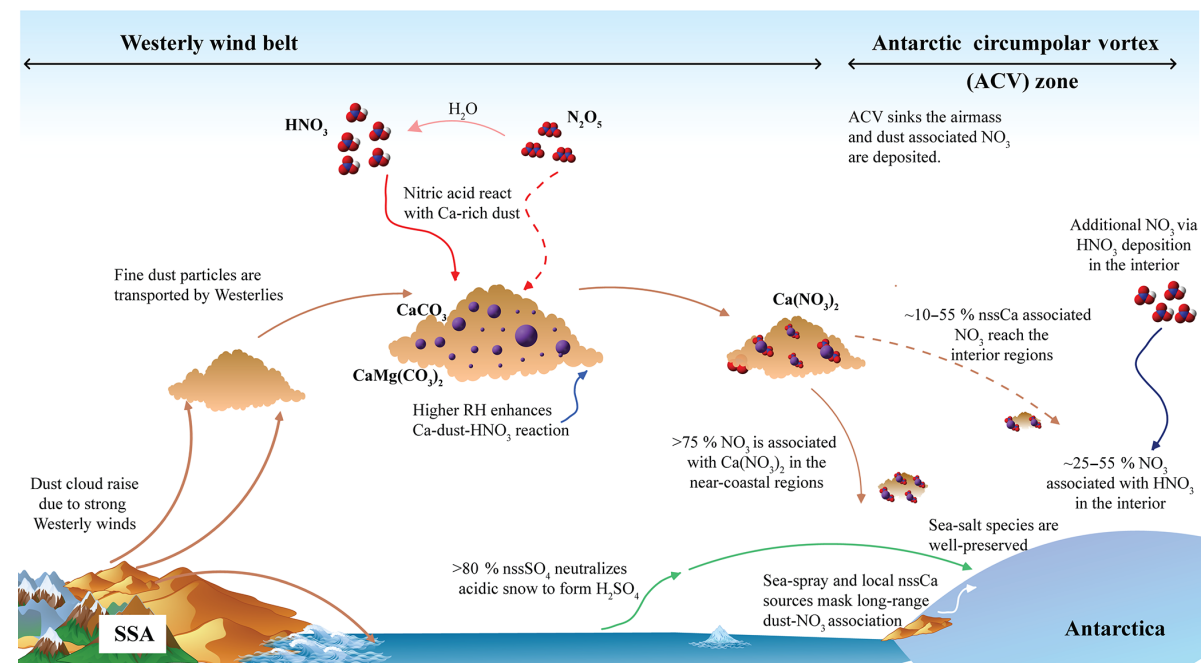

Figure 6. Schematic diagram depicting possible processes and chemical reactions involved during the mineral dust transport from southern South America (SSA) before depositing over Antarctic ice sheet. The estimates of $\mathrm{NO}_{3}^{-}$associated with nssCa ${ }^{2+}$ and $\mathrm{H}^{+}$are based on data from this study.

(2001) have shown that the transport efficiency of dust to East Antarctica is greater at the present day, suggesting that an overall increase in dust transport is more likely. Röthlisberger et al. (2002a) also speculated that such reactions in the atmosphere would result in a widespread $\mathrm{Ca}^{2+} / \mathrm{NO}_{3}^{-}$association throughout Antarctica. However, it remained inconclusive whether such reactions occurred in the atmosphere or in the Antarctic snowpack. Our studies suggest that such association could be widespread, provided the dust-bound nitrate reaches the interior plateau of the continent. However, it is important to consider the possible sources of additional input such as $\mathrm{nssCa}^{2+}$ from the exposed mountains or $\mathrm{ssCa}^{2+}$ from the oceans along the coast in order to statistically detect the association during data analysis. Such reactions are of significance in the Antarctic atmosphere as they have the ability to modify the properties of original aerosols, resulting in modified climate impact, for instance, by variations in light scattering and photochemical activity (Tegen et al., 1997).

\section{Conclusions}

This study shows a strong and widespread association between $\mathrm{nsSCa}^{2+}$ and $\mathrm{NO}_{3}^{-}$in snow from two different regions in cDML and PEL, which are $>2000 \mathrm{~km}$ apart in East Antarctica. We hypothesise that such a strong association is due to the interaction between calcium-rich mineral dust and nitric acid in the atmosphere, resulting in the formation of $\mathrm{Ca}\left(\mathrm{NO}_{3}\right)_{2}$ aerosol. The results from ionic balance and residual acidity show that a majority of $\mathrm{NO}_{3}^{-}$in the coastal region is associated with $\mathrm{nssCa}^{2+}\left(\right.$ as $\left.\mathrm{Ca}\left(\mathrm{NO}_{3}\right)_{2}\right)$, whereas in the inland region $\mathrm{NO}_{3}^{-}$was associated with $\mathrm{H}^{+}$(as $\mathrm{HNO}_{3}$ ). The forward- and back-trajectory analyses suggest that fine calcic mineral dust from the SSA region has been transported to the East Antarctic region, aided by the westerlies. Also, the results from principal component analyses further strengthen our view that $\mathrm{Ca}\left(\mathrm{NO}_{3}\right)_{2}$ was formed in the atmosphere during the transport of mineral dust from SSA to the East Antarctic region. The $\mathrm{Ca}\left(\mathrm{NO}_{3}\right)_{2}$ aerosol thus formed and was deposited over Antarctica under the influence of anticyclonic polar easterlies. Our study also shows that local input of dust and sea spray is more likely to mask the association between $\mathrm{nsSCa}^{2+}$ and $\mathrm{NO}_{3}^{-}$. We propose that, apart from other significant $\mathrm{NO}_{3}^{-}$sources, $\mathrm{NO}_{3}^{-}$associated with mineral dust could form a significant portion of total $\mathrm{NO}_{3}^{-}$deposited in the East Antarctic snow. We also suggest that such association between $\mathrm{Ca}^{2+}$ and $\mathrm{NO}_{3}^{-}$could be widespread but may not be observed clearly when study regions are close to the coast or when additional dust is contributed by local crustal sources.

Author contributions. Both authors contributed equally to the work presented in this paper. K. Mahalinganathan collected samples, analysed data, and wrote the paper. M. Thamban analysed data and wrote the paper.

Acknowledgements. We thank the director of the National Centre for Antarctic and Ocean Research for his encouragement and the Ministry of Earth Sciences for financial support. We are grateful for the support from the members and logistic crew of the 28th Indian Scientific Expedition to Antarctica. Archana Dayal is acknowledged for dust analysis. C. M. Laluraj, B. L. Redkar, and Ashish Painginkar are thanked for laboratory support. We thank the Norwegian Polar Institute for the Quantarctica QGIS package. The authors also thank the editor and two anonymous reviewers 
for their constructive comments, which helped us to improve the manuscript. Kanthanathan Mahalinganathan would like to thank Revathi Jayaram and D. Suguna for language editing. This is NCAOR contribution number 32/2015.

Edited by: F. Dominé

\section{References}

Al-Abadleh, H. A., Krueger, B. J., Ross, J. L., and Grassian, V. H.: Phase transitions in calcium nitrate thin films, Chem. Commun., 22, 2796-2797, doi:10.1039/B308632A, 2003.

Albani, S., Mahowald, N. M., Delmonte, B., Maggi, V., and Winckler, G.: Comparing modeled and observed changes in mineral dust transport and deposition to Antarctica between the Last Glacial Maximum and current climates, Clim. Dynam., 38, 1731-1755, doi:10.1007/s00382-011-1139-5, 2012.

Antony, R., Thamban, M., Krishnan, K. P., and Mahalinganathan, K.: Is cloud seeding in coastal Antarctica linked to bromine and nitrate variability in snow?, Environ. Res. Lett., 5, 014009, doi:10.1088/1748-9326/5/1/014009, 2010.

Basile-Doelsch, I., Grousset, F. E., Revel, M., Petit, J. R., Biscaye, P. E., and Barkov, N. I.: Patagonian origin of glacial dust deposited in East Antarctica (Vostok and Dome C) during glacial stages 2, 4 and 6, Earth Planet. Sc. Lett., 146, 573-589, doi:10.1016/S0012-821X(96)00255-5, 1997.

Berhanu, T. A., Savarino, J., Erbland, J., Vicars, W. C., Preunkert, S., Martins, J. F., and Johnson, M. S.: Isotopic effects of nitrate photochemistry in snow: a field study at Dome C, Antarctica, Atmos. Chem. Phys., 15, 11243-11256, doi:10.5194/acp15-11243-2015, 2015.

Bertler, N., Mayewski, P. A., Aristarain, A., Barrett, P., Becagli, S., Bernardo, R., Bo, S., Xiao, C., Curran, M., Qin, D., Dixon, D. A., Ferron, F., Fischer, H., Frey, M., Frezzotti, M., Fundel, F., Genthon, C., Gragnani, R., Hamilton, G. S., Handley, M., Hong, S., Isaksson, E., Kang, J., Ren, J., Kamiyama, K., Kanamori, S., Kärkäs, E., Karlöf, L., Kaspari, S., Kreutz, K., Kurbatov, A., Meyerson, E., Ming, Y., Zhang, M., Motoyama, H., Mulvaney, R., Oerter, H., Osterberg, E., Proposito, M., Pyne, A., Ruth, U., Simões, J., Smith, B., Sneed, S., Teinilä, K., Traufetter, F., Udisti, R., Virkkula, A., Watanabe, O., Williamson, B., Winther, J.-G., Li, Y., Wolff, E. W., Li, Z., and Zielinski, A.: Snow chemistry across Antarctica, Ann. Glaciol., 41, 167-179, doi:10.3189/172756405781813320, 2005.

Bory, A., Wolff, E. W., Mulvaney, R., Jagoutz, E., Wegner, A., Ruth, U., and Elderfield, H.: Multiple sources supply eolian mineral dust to the Atlantic sector of coastal Antarctica: evidence from recent snow layers at the top of Berkner Island ice sheet, Earth Planet. Sc. Lett., 291, 138-148, doi:10.1016/j.eps1.2010.01.006, 2010.

Boutron, C. and Martin, S.: Sources of twelve trace metals in Antarctic snows determined by principal component analysis, J. Geophys. Res.-Oceans, 85, 5631-5638, doi:10.1029/JC085iC10p05631, 1980.

Brasseur, G. and Solomon, S.: Composition and chemistry, in: Aeronomy of the Middle Atmosphere, Atmospheric and Oceanographic Sciences Library, Springer, the Netherlands, 1986.
Burkhart, J. F., Hutterli, M., Bales, R. C., and McConnell, J. R.: Seasonal accumulation timing and preservation of nitrate in firn at Summit, Greenland, J. Geophys. Res.-Atmos., 109, D19302, doi:10.1029/2004JD004658, 2004.

Coronato, F. R.: Wind chill factor applied to Patagonian climatology, Int. J. Biometeorol., 37, 1-6, doi:10.1007/BF01212759, 1993.

Dahe, Q., Zeller, E. J., and Dreschhoff, G. A. M.: The distribution of nitrate content in the surface snow of the Antarctic Ice Sheet along the route of the 1990 International Trans-Antarctica Expedition, J. Geophys. Res., 97, 6277-6284, doi:10.1029/92JA00142, 1992.

Davis, D. D., Seeling, J., Huey, G., Crawford, J., Chen, G., Wang, Y., Buhr, M., Helmig, D., Neff, W., Blake, D., Arimoto, R., and Eisele, F.: A reassessment of Antarctic plateau reactive nitrogen based on \{ANTCI\} 2003 airborne and ground based measurements, Atmos. Environ., 42, 2831-2848, doi:10.1016/j.atmosenv.2007.07.039, 2008.

Delmonte, B., Basile-Doelsch, I., Petit, J.-R., Maggi, V., Revel-Rolland, M., Michard, A., Jagoutz, E., and Grousset, F.: Comparing the Epica and Vostok dust records during the last 220,000 years: stratigraphical correlation and provenance in glacial periods, Earth-Sci. Rev., 66, 63-87, doi:10.1016/j.earscirev.2003.10.004, 2004.

Dieckmann, G. S., Nehrke, G., Papadimitriou, S., Göttlicher, J., Steininger, R., Kennedy, H., Wolf-Gladrow, D., and Thomas, D. N.: Calcium carbonate as ikaite crystals in Antarctic sea ice, Geophys. Res. Lett., 35, L08501, doi:10.1029/2008GL033540, 2008.

Dixon, D. A., Mayewski, P. A., Goodwin, I. D., Marshall, G. J., Freeman, R., Maasch, K. A., and Sneed, S. B.: An ice-core proxy for northerly air mass incursions into West Antarctica, Int. J. Climatol., 32, 1455-1465, doi:10.1002/joc.2371, 2012.

Draxler, R. and Rolph, G.: HYSPLIT (HYbrid Single-Particle Lagrangian Integrated Trajectory) Model access via NOAA ARL READY Website (http://www.arl.noaa.gov/HYSPLIT. php), NOAA Air Resources Laboratory, College Park, MD, available at: http://ready.arl.noaa.gov/HYSPLIT_ash.php (last access: April 2015), 2014.

Erbland, J., Vicars, W. C., Savarino, J., Morin, S., Frey, M. M., Frosini, D., Vince, E., and Martins, J. M. F.: Air-snow transfer of nitrate on the East Antarctic Plateau - Part 1: Isotopic evidence for a photolytically driven dynamic equilibrium in summer, Atmos. Chem. Phys., 13, 6403-6419, doi:10.5194/acp-136403-2013, 2013.

Erbland. J., Savarino, J., Morin, S., France, J. L., Frey, M. M., and King, M. D.: Air-snow transfer of nitrate on the East Antarctic Plateau - Part 2: An isotopic model for the interpretation of deep ice-core records, 15, 12079-12113, doi:10.5194/acp-15-120792015, 2015.

Fairlie, T. D., Jacob, D. J., Dibb, J. E., Alexander, B., Avery, M. A., van Donkelaar, A., and Zhang, L.: Impact of mineral dust on nitrate, sulfate, and ozone in transpacific Asian pollution plumes, Atmos. Chem. Phys., 10, 3999-4012, doi:10.5194/acp-10-39992010, 2010.

Gaiero, D. M.: Dust provenance in Antarctic ice during glacial periods: from where in southern South America?, Geophys. Res. Lett., 34, L17707, doi:10.1029/2007GL030520, 2007. 
Gaiero, D. M., Simonella, L., Gassó, S., Gili, S., Stein, A. F., Sosa, P., Becchio, R., Arce, J., and Marelli, H.: Ground/satellite observations and atmospheric modeling of dust storms originating in the high Puna-Altiplano deserts (South America): implications for the interpretation of paleoclimatic archives, J. Geophys. Res.-Atmos., 118, 3817-3831, doi:10.1002/jgrd.50036, 2013.

Gassó, S., Stein, A., Marino, F., Castellano, E., Udisti, R., and Ceratto, J.: A combined observational and modeling approach to study modern dust transport from the Patagonia desert to East Antarctica, Atmos. Chem. Phys., 10, 8287-8303, doi:10.5194/acp-10-8287-2010, 2010.

Gibson, E. R., Hudson, P. K., and Grassian, V. H.: Physicochemical properties of nitrate aerosols: Implications for the atmosphere, J. Phys. Chem. A, 110, 11785-11799, doi:10.1021/jp063821k, 2006.

Goodman, A. L., Underwood, G. M., and Grassian, V. H.: A laboratory study of the heterogeneous reaction of nitric acid on calcium carbonate particles, J. Geophys. Res.-Atmos., 105, 2905329064, doi:10.1029/2000JD900396, 2000.

Iizuka, Y., Takata, M., Hondoh, T., and Fujii, Y.: High-timeresolution profiles of soluble ions in the last glacial period of a Dome Fuji (Antarctica) deep ice core, 39, 452-456, doi:10.3189/172756404781814302, 2004.

Iriondo, M.: Quaternary lakes of Argentina, Palaeogeogr. Palaeocl., 70, 81-88, doi:10.1016/0031-0182(89)90081-3, 1989.

Iriondo, M.: Patagonian dust in Antarctica, Quaternary Int., 68-71, 83-86, doi:10.1016/S1040-6182(00)00035-5, 2000.

Jordan, C. E., Dibb, J. E., Anderson, B. E., and Fuelberg, H. E.: Uptake of nitrate and sulfate on dust aerosols during TRACE-P, J. Geophys. Res., 108, 8817, doi:10.1029/2002JD003101, 2003.

Krueger, B. J., Grassian, V. H., Laskin, A., and Cowin, J. P.: The transformation of solid atmospheric particles into liquid droplets through heterogeneous chemistry: laboratory insights into the processing of calcium containing mineral dust aerosol in the troposphere, Geophys. Res. Lett., 30, 1148, doi:10.1029/2002GL016563, 2003.

Krueger, B. J., Grassian, V. H., Cowin, J. P., and Laskin, A.: Heterogeneous chemistry of individual mineral dust particles from different dust source regions: the importance of particle mineralogy, Atmos. Environ., 38, 6253-6261, doi:10.1016/j.atmosenv.2004.07.010, 2004.

Lambert, F., Delmonte, B., Petit, J. R., Bigler, M., Kaufmann, P. R., Hutterli, M. A., Stocker, T. F., Ruth, U., Steffensen, J. P., and Maggi, V.: Dust-climate couplings over the past 800,000 years from the EPICA Dome C ice core, Nature, 452, 616-619, doi:10.1038/nature06763, 2008.

Laskin, A., Wietsma, T. W., Krueger, B. J., and Grassian, V. H.: Heterogeneous chemistry of individual mineral dust particles with nitric acid: a combined CCSEM/EDX, ESEM, and ICP-MS study, J. Geophys. Res., 110, D10208, doi:10.1029/2004JD005206, 2005.

Lee, H.-M., Henze, D. K., Alexander, B., and Murray, L. T.: Investigating the sensitivity of surface-level nitrate seasonality in Antarctica to primary sources using a global model, Atmos. Environ., 89, 757-767, doi:10.1016/j.atmosenv.2014.03.003, 2014.

Legrand, M. R. and Delmas, R. J.: Relative contributions of tropospheric and stratospheric sources to nitrate in Antarctic snow, Tellus B, 38, 236-249, doi:10.1111/j.16000889.1986.tb00190.x, 1986.
Legrand, M. R. and Mayewski, P. A.: Glaciochemistry of polar ice cores: a review, Rev. Geophys., 35, 219-243, doi:10.1029/96RG03527, 1997.

Legrand, M. R., Wolff, E. W., and Wagenbach, D.: Antarctic aerosol and snowfall chemistry: Implications for deep Antarctic ice-core chemistry, Ann. Glaciol., 29, 66-72, doi:10.3189/172756499781821094, 1999.

Li, F., Ginoux, P., and Ramaswamy, V.: Distribution, transport, and deposition of mineral dust in the Southern Ocean and Antarctica: contribution of major sources, J. Geophys. Res., 113, D10207, doi:10.1029/2007JD009190, 2008.

Li, F., Ginoux, P., and Ramaswamy, V.: Transport of Patagonian dust to Antarctica, J. Geophys. Res., 115, D18217, doi:10.1029/2009JD012356, 2010.

Lunt, D. J. and Valdes, P. J.: Dust transport to Dome C, Antarctica, at the Last Glacial Maximum and present day, Geophys. Res. Lett., 28, 295-298, doi:10.1029/2000GL012170, 2001.

Mahalinganathan, K., Thamban, M., Laluraj, C. M., and Redkar, B. L.: Relation between surface topography and sea-salt snow chemistry from Princess Elizabeth Land, East Antarctica, The Cryosphere, 6, 505-515, doi:10.5194/tc-6-505-2012, 2012.

Mahowald, N. M., Albani, S., Kok, J. F., Engelstaeder, S., Scanza, R., Ward, D. S., and Flanner, M. G.: The size distribution of desert dust aerosols and its impact on the Earth system, Aeolian Res., 15, 53-71, doi:10.1016/j.aeolia.2013.09.002, 2013.

Michalski, G., Bockheim, J. G., Kendall, C., and Thiemens, M.: Isotopic composition of Antarctic Dry Valley nitrate: implications for $\mathrm{NO}_{y}$ sources and cycling in Antarctica, Geophys. Res. Lett., 32, L13817, doi:10.1029/2004GL022121, 2005.

Mogili, P. K., Kleiber, P. D., Young, M. A., and Grassian, V. H.: Heterogeneous uptake of ozone on reactive components of mineral dust aerosol: an environmental aerosol reaction chamber study, J. Phys. Chem. A, 110, 13799-13807, doi:10.1021/jp063620g, 2006.

Nousiainen, T. and Kandler, K.: Light scattering by atmospheric mineral dust particles, in: Light Scattering Reviews 9, edited by: Kokhanovsky, A. A., Springer Praxis Books, Springer, Berlin, Heidelberg, 3-52, doi:10.1007/978-3-642-37985-7_1, 2015.

Pye, K.: Chapter six - Grain size, mineralogy and chemical composition of aeolian dust, in: Aeolian Dust and Dust Deposits, edited by: Pye, K., Academic Press Inc. Ltd, London, 118-141, doi:10.1016/B978-0-12-568690-7.50010-7, 1987.

Revel-Rolland, M., De Deckker, P., Delmonte, B., Hesse, P. P., Magee, J. W., Basile-Doelsch, I., Grousset, F., and Bosch, D.: Eastern Australia: a possible source of dust in East Antarctica interglacial ice, Earth Planet. Sc. Lett., 249, 1-13, doi:10.1016/j.epsl.2006.06.028, 2006.

Röthlisberger, R., Hutterli, M. A., Sommer, S., Wolff, E. W., and Mulvaney, R.: Factors controlling nitrate in ice cores: evidence from the Dome C deep ice core, J. Geophys. Res., 105, 2056520572, doi:10.1029/2000JD900264, 2000.

Röthlisberger, R., Hutterli, M. A., Wolff, E. W., Mulvaney, R., Fischer, H., Bigler, M., Goto-Azuma, K., Hansson, M. E., Ruth, U., Siggaard-Andersen, M.-L., and Steffensen, J. P.: Nitrate in Greenland and Antarctic ice cores: a detailed description of post-depositional processes, Ann. Glaciol., 35, 209-216, doi:10.3189/172756402781817220, 2002a.

Röthlisberger, R., Mulvaney, R., Wolff, E. W., Hutterli, M. A., Bigler, M., Sommer, S., and Jouzel, J.: Dust and sea salt vari- 
ability in central East Antarctica (Dome C) over the last $45 \mathrm{kyrs}$ and its implications for southern high-latitude climate, Geophys. Res. Lett., 29, 1963, doi:10.1029/2002GL015186, 2002b.

Ruth, U., Barbante, C., Bigler, M., Delmonte, B., Fischer, H., Gabrielli, P., Gaspari, V., Kaufmann, P., Lambert, F., Maggi, V., Marino, F., Petit, J.-R., Udisti, R., Wagenbach, D., Wegner, A., and Wolff, E. W.: Proxies and measurement techniques for mineral dust in Antarctic ice cores, Environ. Sci. Technol., 42, 56755681, doi:10.1021/es703078z, 2008.

Savarino, J., Kaiser, J., Morin, S., Sigman, D. M., and Thiemens, M. H.: Nitrogen and oxygen isotopic constraints on the origin of atmospheric nitrate in coastal Antarctica, Atmos. Chem. Phys., 7, 1925-1945, doi:10.5194/acp-7-1925-2007, 2007.

Schüpbach, S., Federer, U., Kaufmann, P. R., Albani, S., Barbante, C., Stocker, T. F., and Fischer, H.: High-resolution mineral dust and sea ice proxy records from the Talos Dome ice core, Clim. Past, 9, 2789-2807, doi:10.5194/cp-9-2789-2013, 2013.

Shi, G., Buffen, A. M., Hastings, M. G., Li, C., Ma, H., Li, Y., Sun, B., An, C., and Jiang, S.: Investigation of post-depositional processing of nitrate in East Antarctic snow: isotopic constraints on photolytic loss, re-oxidation, and source inputs, Atmos. Chem. Phys., 15, 9435-9453, doi:10.5194/acp-15-9435-2015, 2015.

Sommer, S., Wagenbach, D., Mulvaney, R., and Fischer, H.: Glacio-chemical study spanning the past $2 \mathrm{kyr}$ on three ice cores from Dronning Maud Land, Antarctica: 2. Seasonally resolved chemical records, J. Geophys. Res., 105, 29423-29433, doi:10.1029/2000JD900450, 2000.

Stenberg, M., Isaksson, E., Hansson, M., Karlén, W., Mayewski, P. A., Twickler, M. S., Whitlow, S. I., and Gundestrup, N.: Spatial variability of snow chemistry in western Dronning Maud Land, Antarctica, Ann. Glaciol., 27, 378-384, 1998.

Tegen, I. and Lacis, A. A.: Modeling of particle size distribution and its influence on the radiative properties of mineral dust aerosol, J. Geophys. Res., 101, 19237-19244, doi:10.1029/95JD03610, 1996.

Tegen, I., Hollrig, P., Chin, M., Fung, I., Jacob, D., and Penner, J.: Contribution of different aerosol species to the global aerosol extinction optical thickness: estimates from model results, J. Geophys. Res., 102, 23895-23915, doi:10.1029/97JD01864, 1997.

Traversi, R., Udisti, R., Frosini, D., Becagli, S., Ciardini, V., Funke, B., Lanconelli, C., Petkov, B., Scarchilli, C., Severi, M., and Vitale, V.: Insights on nitrate sources at Dome C (East Antarctic Plateau) from multi-year aerosol and snow records, Tellus B, 66, 22550, doi:10.3402/tellusb.v66.22550, 2014.
Udisti, R., Becagli, S., Benassai, S., Castellano, E., Fattori, I., Innocenti, M., and Migliori, A., and Traversi, R.: Atmospheresnow interaction by a comparison between aerosol and uppermost snow-layers composition at Dome C, East Antarctica, Ann. Glaciol., 39, 53-61, doi:10.3189/172756404781814474, 2004.

Usher, C. R., Michel, A. E., and Grassian, V. H.: Reactions on mineral dust, Chem. Rev., 103, 4883-4939, doi:10.1021/cr020657y, 2003.

Wagenbach, D., Legrand, M. R., Fischer, H., Pichlmayer, F., and Wolff, E. W.: Atmospheric near-surface nitrate at coastal Antarctic sites, J. Geophys. Res., 103, 11007-11020, doi:10.1029/97JD03364, 1998.

Wagnon, P., Delmas, R. J., and Legrand, M. R.: Loss of volatile acid species from upper firn layers at Vostok, Antarctica, J. Geophys. Res., 104, 3423-3431, doi:10.1029/98JD02855, 1999.

Weller, R.: Postdepositional losses of methane sulfonate, nitrate, and chloride at the European Project for Ice Coring in Antarctica deep-drilling site in Dronning Maud Land, Antarctica, J. Geophys. Res., 109, D07301, doi:10.1029/2003JD004189, 2004.

Weller, R., Jones, A. E., Wille, A., Jacobi, H.-W., McIntyre, H. P., Sturges, W. T., Huke, M., and Wagenbach, D.: Seasonality of reactive nitrogen oxides $\left(\mathrm{NO}_{y}\right)$ at Neumayer Station, Antarctica, J. Geophys. Res., 107, 4673, doi:10.1029/2002JD002495, 2002.

Weller, R., Wagenbach, D., Legrand, M. R., Elsässer, C., TianKunze, X., and König-Langlo, G.: Continuous 25-yr aerosol records at coastal Antarctica - I: inter-annual variability of ionic compounds and links to climate indices, Tellus B, 63, 901-919, doi:10.1111/j.1600-0889.2011.00542.x, 2011.

Wolff, E. W.: Nitrate in Polar Ice, in: Ice Core Studies of Global Biogeochemical Cycles, vol. 30 of NATO ASI Series, edited by: Delmas, R., Springer, Berlin, Heidelberg, 195-224, doi:10.1007/978-3-642-51172-1_10, 1995.

Wolff, E. W.: Ice sheets and nitrogen, Philos. T. Roy. Soc. B, 368, 20130127, doi:10.1098/rstb.2013.0127, 2013.

Zárate, M. A.: Loess of southern South America, Quaternary Sci. Rev., 22, 1987-2006, doi:10.1016/S0277-3791(03)00165-3, 2003. 